\title{
THE PORTRAYAL OF WOMEN IN THE GREAT GATSBY BY F. SCOTT FITZGERALD AND IT'S RELATIONSHIP TO INDONESIAN WOMEN ON EDUCATION
}

\author{
Himawan Agung Rida Pambudi \\ University of Bengkulu \\ agungedsaunib@gmail.com \\ Barnabas Sembiring \\ University of Bengkulu \\ barnabas_Sembiring@yahoo.com \\ Indah Damayanti \\ University of Bengkulu \\ indah_0789@yaho.co.id
}

\begin{abstract}
ABSTRAK
Penelitian ini bertujuan untuk menemukan dan menjelaskan secara detail sifat dan watak dari karakter wanita di dalam novel, untuk mengetahui bagaimana novel dan pengarang menggambarkan karakter dan sifat dari tokoh utama wanita di dalam novel serta bagaimana penggambaran wanita Indonesia di dalam bidang Pendidikan. Berdasarkan dari data yang telah diperoleh, peneliti mendapatkan hasil yang menunjukkan penggambaran watak dari 3 tokoh utama wanita. Daisy Buchanan memiliki 2 sifat, yaitu Pessimistic dan Materialistic, Jordan Baker juga memiliki 2 sifat, yaitu Masculine dan Worried, dan karakter terakhir yaitu Myrtle Wilson yang memiliki sifat Materialistic. Disamping itu, peneliti juga menjelaskan penggambaran tokoh wanita di dalam novel dan mengaitkannya pada era 1920 dimana pertama kali novel diterbitkan. Peneliti juga membandingkan dan menjelaskan karakteristik dan sifat dari wanita Amerika di dalam novel dan karakteristik dari wanita Indonesia.
\end{abstract}

Kata Kunci: Karakteristik, Tokoh Wanita, Novel

\begin{abstract}
This research is aimed to find out and explain the characteristics of women character, to know how the novel portrayed the women and how Indonesian women on education portrayed. According to the data, the researcher gets the result that show characteristics of 3 major women characters. Daisy Buchanan has two characteristics, there are Pessimistic and Materialistic, Jordan Baker also has two, Masculine and Worried, and the last is Myrtle Wilson is Materialistic. Besides that, the researcher also explains the portrayal of women in the novel and relate it to the 1920s era where does the novel come from. The researcher also compared and portrayed the characteristics of American women in the novel and Indonesian women characters.
\end{abstract}

Keywords: Characteristics, Women Character, Novel 


\section{INTRODUCTION}

Literature has been known by many people and become a part of life. Literature also has a function as a messenger to the societies for all the polemic and problems that exist, so we can have a picture of what we should do when we face with the same problems that occur in a literature. Furthermore, literature is the representation of a society and it portrays the condition of an era. Literature itself is the result of fantasy that is satisfied by the writer through his imagination, although the literature is created from the imagination of the author, but his work still comes from a real life. Klarer (2004:1) says that in most cases, literature refers to the entirety of written expression, with the restriction that not every written document can be categorized as literature in the more exact sense of the word. Literature as a writing form differentiates its form from other art products, and its aesthetic or artistic values make it different from other writings.

A kind of literature is novel. Novel (from the Italian novella, Spanish novela, French nouvelle for "new", "news", or "short story of something new"), the new story (novel) comes after drama and poetry (Tarigan, 1985: 64). Novel is the further development of romance. A novel is defined as a fictitious prose narrative of considerable length and complexity, portraying characters and usually presenting a sequential organization of action and scenes.

Every kind of literature has intrinsic and extrinsic elements. The intrinsic elements of novel are: theme, character, plot, setting, symbol and point of view. Meanwhile, the extrinsic elements are: author background, historical view, cultural background and social background. Every component has the main role to make the literature is more interesting and enjoyable for people. Character is the most important aspect that must be appeared in literary work including novel, poetry, drama, and short stories. Generally, in human character, there are two main characters namely: men and women character. Both man and women character have a portrayal in the societies, positively and negatively.

Especially for women character, they pay more attention in the context of their characteristic, lifestyle, attitude, and speaking style. It causes the woman character has different portrayal than man character. In 1920s, the women began to grow more independent. American women were transformed after World War I. They seemed to embody the changes that were going on in the country itself. The United States went from a young industrial state that was accumulating the capital to build factories and railroads to a world power with a consumer economy that relied on its citizen to keep the boom going by borrowing money and buying homes and cars. Meanwhile, the celibate settlement house worker was replaced as a female prototype by the jazz-crazed flapper dancing the Charleston in a speakeasy.

Flappers were a generation of young Western women in the 1920s who wore short skirts, bobbed their hair, listened to jazz, and flaunted their disdain for what was then considered acceptable behavior. The flapper is one of the most essential parts of the 1920s. She represented a 'new' type of woman. Whether in attitude, attire, or slang, the 1920s flapper demonstrated how women could actively transform what is into what can be, something that is a part of the modern construction of women's identity. Everything that had anything to do with 
consumption was in style. That included drinking, smoking, and sex for women as well as men. (America's Women, 400 years of Dolls, Drudges, Helpmates and Heroines' by Gail Collins).

In this research, the researcher will analyze and give an explanation about the women characteristic and the portrayal of women character in The Great Gatsby. The Great Gatsby is a novel 1925 written in by American author F. Scott Fitzgerald. He portrays the fictional town of West Egg on prosperous Long Island in the summer of 1922. In this novel, the researcher focuses on describing the characteristic of women characters, describe the portrayal of women in 1920s and also how Indonesian women on education portrayed.

This research had three research questions were "What are the characteristics of women character in The Great Gatsby by F. Scott Fitzgerald?" and "How does the novel portray women in The Great Gatsby by F. Scott Fitzgerald?" the last "How does the Indonesian women on education portrayed?"

The researcher expected this research will give some influences both academically and practically, and the further researchers as well.

\section{METHOD}

In this research, will be applied a descriptive qualitative method. The descriptive study is an appropriate way to expose facts related to the problem which is going to be discussed. According to Gay (1991), descriptive method is considered appropriate to describe the present condition of research subject.

Darsono (1997) also states that descriptive research is a research which effort to give a phenomenon or a situation naturally without manipulation toward one of the variables. Content analysis or document analysis is systematically studying record, document, book, picture, curriculum, texts book, novel, article, composition, photograph, and another. Based on the opinions, the researcher designs this research as descriptive research.

Instrument that the researcher used in this research is documentation (library research). It means the researcher use and read the novel of The Great Gatsby by F. Scott Fitzgerald as a primary data to find out the data and information about the characteristics of women, then how does novel portrayed women in The Great Gatsby by F. Scott Fitzgerald and classifying characteristics of women character in novel and Indonesian women character.

The object of this research is a novel entitled The Great Gatsby written by F. Scott Fitzgerald. In this research, the researcher chooses the population and sample from the novel. As Thomas Crowl states that "Population are groups consisting of all people to whom a researcher wishes to apply the findings of a study". Crowl also states that "sample are subsets of people used to represent populations." (1996)

\section{Technique of Data Collection}

The researcher uses several steps to collect the data, First, the researcher reading The Great Gatsby by F. Scott Fitzgerald (as primary data). Second, repeating the same way (reading The Great Gatsby) for several times. Third, identifying the women characters who play important roles in novel The Great Gatsby and how novel portrays the women in that novel. Fourth, analyzing the women character who play important roles and conclude how novel portrayed women in The Great Gatsby. Fifth, classifying characteristics of women character in novel and Indonesian women 
character. Last is Adding some information about American Women characteristics in 1920s from journal and literature resources. and then making conclusion.

\section{Technique of Data Analysis}

The researcher conducts the data analysis with the following procedures: first finding the characteristics of women character in The Great Gatsby by F. Scott Fitzgerald, second is classifying the major women character and minor women character based on the plot/ situation in the story, third describing the portrayal of women character from The Great Gatsby, fourth classifying characteristics of women character in novel and Indonesian women character and the last is drawing the conclusion and suggestion based on the analysis.

\section{RESULTS AND DISCUSSION}

\section{Characteristics of women character}

\section{Daisy Buchanan}

Daisy Buchanan, born Daisy Fay, is from a wealthy family in Louisville, Kentucky, popular and beautiful, she was become an idol and make several officers falling in love during World War I. She met and fell in love with Jay Gatsby, an officer at the time, and promised to wait for him to return from the war. However, she gave up to pressure from her family and married Tom Buchanan instead. The next year, they had a baby girl together, Pammy. Although Daisy is happy immediately after she and Tom are married, he begins having affairs almost immediately after their honeymoon to the South Seas. By the beginning of the novel, Daisy and Tom hope to stay in New York permanently. Daisy frequently hosts her friend Jordan Baker, and looked sad for something or someone to distract her from her nervous and increasing pessimism.

\section{A. Pessimistic}

Pessimistic is thinking that bad things are more likely to happen or emphasizing the bad part of a situation (Cambridge Dictionary). Pessimistic in this novel came from the first time we meet Daisy in Chapter 1. She has just finished telling Nick about how when she gave birth to her daughter, she woke up alone. So beside her charming surface, Daisy also sad about her role in the world and unhappily married to Tom. The deeply pessimistic comment in the following quote.

"She told me it was a girl, and so I turned my head away and wept. All right, I said. I'm glad it's a girl. And I hope she'll be a fool - that's the best thing a girl can be in this world, a beautiful little fool" (Fitzgerald, 1925:118)

After that comment, Nick (narrator in this novel) describes about Daisy's "smirking", which is shows her pessimism as stated on following passage.

"Here, dearis." She groped around in a waste-basket she had with her on the bed and pulled out the string of pearls. "Take 'em downstairs and give 'em back to whoever they belong to. Tell 'em all Daisy's change' her mine. Say 'Daisy's change' her mine!'. She began to cry - she cried and cried. I rushed out and found her mother's maid and we locked the door and got her into a cold bath. She wouldn't let go of the letter. She took it into the tub with her and squeezed it up into a wet ball, and only let me leave it in the soap dish when she saw that it was coming to pieces like snow. But she didn't say another word. We gave her spirits of ammonia and put ice on her forehead and hooked her back into her dress and half an hour later when we walked out of the room the pearls were around her neck and the incident was over. Next day at five o'clock she married Tom Buchanan without so much as a shiver and started 
off on a three months' trip to the South Seas." (Fitzgerald, 1925:140-2)

In this flashback narrated by Jordan, it informs about Daisy's past and how she came to marry Tom, despite she still being in love with Jay Gatsby. In fact, she seems to care about him enough after receiving a letter from him, she threatens to call of her marriage to Tom. And indeed, the next day she marries Tom, showing her reluctante to question the place in society dictated by her family and social status.

\section{B. Materialistic}

Materialistic means overly concerned or preoccupied with material possessions rather than with intellectual or spiritual things (Merriam- Webster Dictionary), in a simple thing called by desiring luxury. It informs during Daisy and Gatsby's reunion, she is delighted by Gatsby's mansion but falls to pieces after Gatsby shows off his collection of shirt. as stated on following passage. "They're such beautiful shirts, she sobbed, her voice muffled in the thick folds. It makes me sad because I've never seen such - such beautiful shirts before." (Fitzgerald, 1925:118).

This scene shows about Daisy's materialism, she only emotionally breaks down at Gatsby's newfound wealth. But it also speaks to her strong feelings for Gatsby. In chapter 7, as Daisy tries to tell Tom she wants to leave him, it is difficult to find meaning and purpose in her life. Instead of her cheerful outlook, there is a deep sadness. as stated on following passage.

"What will we do with ourself this afternoon, cried Daisy, and the day after that, and the next thirty years?" (Fitzgerald, 1925:74). "Her voice is full of money, he said suddenly. That was it. I'd never understood before. It was full of money - that was the inexhaustible charm that rose and fell in it, the jingle of it, the cymbals' song of it... High in a white palace the king's daughter, the golden girl... (Fitzgerald, 1925:105-106) Gatsby explicitly ties Daisy and her magnetic voice to wealth. this part is crucial, since it ties Gatsby's love for Daisy to his pursuit of wealth and status. It also allows Daisy herself to become a stand-in for the idea of the American Dream. During the climatic confrontation in New York City, Daisy can't bring herself to admit she only loved Gatsby, because she did also love Tom at the beginning of their marriage. This moment is crushing for Gatsby. as stated on following passage. "Oh you want too much! she cried to Gatsby. I love you now - isn't that enough? I can't help what's past. She began to sob helplessly. I did love him once - but I loved you too." (Fitzgerald, 1925:264).

\section{Jordan Baker}

Jordan Baker, who is two years younger than Daisy, grew up with the other woman in Louisville. Jordan witnesses both Daisy's initial relationship with Gatsby and how she almost didn't marry Tom after getting a letter from Gatsby but pulled herself together in time for the wedding. Jordan doesn't have any major surviving relatives other than an old aunt who controls her money, so it's implied she's the heiress to a significant amount of money but, during the novel at least, she doesn't have full access to it. Instead of marrying, Jordan plays golf professionally and dates around.

\section{A. Masculine Qualities}

Masculine means having qualities appropriate to or usually associated with a man (Merriam-Webster Dictionary). In here, Jordan Baker have hobbies like men (golf and car) and she looks more 
attractive. Different with Daisy, Jordan explains clearly in this novel start from her gray eyes, her wan, charming face, her small breasts, the slender muscles in her arms. Jordan is blond and very athletic, physical, tan and angular. Physical Description of Jordan stated in the following quote below.

"The younger of the two was a stranger to me. She was extended full length at her end of the divan, completely motionless and with her chin raised a little as if she were balancing something on it which was quite likely to fall. If she saw me out of the corner of her eyes she gave no hint of it-indeed, I was almost surprised into murmuring an apology for having disturbed her by coming in." (Fitzgerald, 1925:28) "I enjoyed looking at her. She was a slender, small-breasted girl, with an erect carriage which she accentuated by throwing her body backward at the shoulders like a young cadet. Her grey sun-strained eyes looked back at me with polite reciprocal curiosity out of a wan, charming discontented face. It occurred to me now that I had seen her, or a picture of her, somewhere before."( Fitzgerald,

1925:57)

"Tom and Miss Baker sat at either end of the long couch and she read aloud to him from the "Saturday Evening Post"-the words, murmurous and uninflected, running together in a soothing tune. The lamp-light, bright on his boots and dull on the autumn-leaf yellow of her hair, glinted along the paper as she turned a page with a flutter of slender muscles in her arms." (Fitzgerald, 1925:121)

\section{B. sw}

Careful, means filling with care or solicitude (Merriam- Webster Dictionary). In this novel, Jordan Baker described as someone who carefully calculate risks, include in driving and in relationships. This is why she brings up her car accident analogy again at the end of the novel when she and Nick break up, about Jordan who calculates risks it stated through the passage below.

"You're a rotten driver," I protested. "Either you ought to be more careful or you oughtn't to drive at all." "I am careful." "No, you're not." "Well, other people are," she said lightly. "What's that got to do with it?" "They'll keep out of my way," she insisted. "It takes two to make an accident." "Suppose you met somebody just as careless as yourself." "I hope I never will," she answered. "I hate careless people. That's why I like you." (Fitzgerald, 1925:162-169) From citation above, get a sense of what draws Jordan and Nick together, he is attracted to her carefree, entitled attitude while she sees his cautiousness as a plus.

\section{Myrtle Wilson}

Unlike Nick's description of Daisy, which focuses on her voice, mannerisms, and charm, and unlike his description of Jordan, which focuses on her posture and athleticism, Nick's description of Myrtle focuses almost entirely on her body itself. Perhaps this fits with her role as Tom's mistress, but it also indicates Nick sees little in Myrtle in terms of intellect or personality. This description also speaks to the strong physical attraction between Tom and Myrtle that become a basic of their affair and it stated in the following passage below.

"Then I heard footsteps on the stairs and in a moment the thickish figure of a woman blocked out the light from the office door. She was in the middle thirties, and faintly stout, but she carried her surplus flesh sensuously as some women can. Her face, above a spotted dress of dark blue crepe-de-chine, contained no facet or gleam of beauty but there was an immediately perceptible vitality about her as if the nerves of her body were 
continually smouldering. She smiled slowly and walking through her husband as if he were a ghost shook hands with Tom, looking him flush in the eye." (Fitzgerald, 1925:15)

\section{A.Materialistic}

Materialistic mean that having money and possessions is the most important thing in life (Cambridge Dictionary). In this novel, Myrtle love her husband when they got married, but has since been disappointed by his lack of cash and social status and it stated in the following passage below.

"I married him because I thought he was a gentleman," she said finally. "I thought he knew something about breeding, but he wasn't fit to lick my shoe."

"You were crazy about him for a while," said Catherine.

"Crazy about him!" cried Myrtle incredulously. "Who said I was crazy about him? I never was any more crazy about him than I was about that man there."

She pointed suddenly at me, and everyone looked at me accusingly. I tried to show by my expression that I had played no part in her past.

"The only crazy I was was when I married him. I knew right away I made a mistake. He borrowed somebody's best suit to get married in and never even told me about it, and the man came after it one day when he was out. She looked around to see who was listening: " 'Oh, is that your suit?' I said. 'This is the first I ever heard about it.' But I gave it to him and then I lay down and cried to beat the band all afternoon." "She really ought to get away from him," resumed Catherine to me. "They've been living over that garage for eleven years. And Tom's the first sweetie she ever had." (Fitzgerald, 1925:112-7).
She begins her affair with Tom Buchanan after he sees her on the train and later presses against her in the station and it stated in the following passage below:

"I was going up to New York to see my sister and spend the night. He had on a dress suit and patent leather shoes and I couldn't keep my eyes off him but every time he looked at me I had to pretend to be looking at the advertisement over his head. When we came into the station he was next to me and his white shirt-front pressed against my arm--and so I told him I'd have to call a policeman, but he knew I lied. I was so excited that when I got into a taxi with him I didn't hardly know I wasn't getting into a subway train" (Fitzgerald, 1925:120).

Myrtle desperately wants to come off as sophisticated and wealthy despite her humble roots. Nick finds her efforts tacky and vulgar, and he spends a lot of time commenting on her clothes, mannerisms, and conversational style. She is oblivious about upper-class life: she tells her sister at one points Tom doesn't divorce Daisy because Daisy is Catholic. This is a small inside joke on Fitzgerald's part - since Tom and Daisy are part of the community of uberWASPy residents of East Egg, there's almost no chance that Daisy could be Catholic. That Myrtle thinks accepts Tom's lie shows that she is not a wellschooled as she thinks she is about the life and customs of the elite class she wants to be a part of. Still, before the novel begins, Tom has gotten comfortable showing Myrtle around in popular restaurants and doesn't hide the affair. Perhaps this causes Myrtle to misunderstand what she means to Tom: she doesn't seem to realize she's just one in a string of mistresses.

Portrayal of Women in The Great Gatsby 


\section{Money and Materialism}

In The Great Gatsby, money is a huge motivator in the characters' relationships, motivations, and outcomes. Most of the characters reveal themselves to be materialistic, their motivations come from their desire for money and things: Daisy married and stay with Tom because of the lifestyle he can provide her, Myrtle has her affair with Tom because of the wealthy provides and give guarantee for her.

In the opening pages, Nick (The Great Gatsby's narrator and also Daisy Buchanan's cousin) establishes himself as someone who has had many advantages in life, a wealthy family and an Ivy League education to name just two. Despite not being as wealthy as Tom and Daisy, his second cousin, they see him as enough of a peer to invite him to their home in Chapter 1. Nick's connection to Daisy in turn makes him attractive to Gatsby. If Nick were just a middle-class everyman, the story could not play out in the same way.

Tom and Daisy's movements are also supported by their money. At the beginning of the novel they move to fashionable East Egg, after moving around between "wherever people played polo and were rich together," and are able to very quickly pick up and leave at the end of the book after the murders, thanks to the protection their money provides (Fitzgerald, 1925:17).

Daisy, for her part, only begins her affair with Gatsby after a very detailed display of his wealth (via the mansion tour). She even breaks down in tears after Gatsby shows off his ridiculously expensive set of colored shirts, crying that she's "never seen such beautiful shirts" before (Fitzgerald, 1925:118).

Gatsby is famous, his enormous wealth, wealth he has gathered to win over Daisy. Gatsby was born to poor farmer parents in North Dakota, but at 17 , determined to become rich, struck out with the wealthy Dan Cody and never looked back (Fitzgerald, 1925:5-15). Even though he wasn't able to get any part of Cody's fortune, he used what he learned of wealthy society to first charm Daisy before shipping out to World War I. (In a uniform she had no idea he was poor, especially given his sophisticated manners). Then, after returning home and realizing Daisy was married and gone, he set out to earn enough money to win Daisy over, turning to crime via a partnership with Meyer Wolfshiem to quickly amass wealth (Fitzgerald, 1925:83-7).

Meanwhile, Tom's mistress Myrtle Wilson, George Wilson's wife, show and tries to pass as rich through her affair with Tom, but her involvement with the Buchanans gets her killed. George Wilson, in contrast, is constrained by his lack of wealth. He tells Tom Buchanan after finding out about Myrtle's affair that he plans to move her West, but he "[needs] money pretty bad" in order to make the move (Fitzgerald, 1925:146). Tragically, Myrtle is hit and killed that evening by Daisy. If George Wilson had means, he likely would have already left New York with Myrtle in car, saving both of their lives.

No one shows up to Gatsby's funeral since they were only attracted by his wealth and the parties, not the man himself. This is resume in a phone call Nick describes, to a man who used to come to Gatsby's parties: "one gentleman to whom I telephoned implied that he had got what he deserved. However, that was my fault, for he was one of those who used to sneer most bitterly at Gatsby on the courage of Gatsby's liquor and I should have known better than to call him" (Fitzgerald, 1925:69). 


\section{Love and Relationship}

Love and relationship are great motivators for nearly every character in The Great Gatsby. Gatsby's portrayal of love and relationship in complex way. So it will be explore and analyze each of Gatsby's five major relationships: Daisy/Tom, George/Myrtle, Gatsby/Daisy, Tom/Myrtle, and Jordan/Nick.

\subsection{Daisy and Tom Marriage Description}

Daisy appeared quite in love when they first got married, but the realities of the marriage, including Tom's multiple affairs, Tom cheated on her soon after their honeymoon, according to Jordan: "It was touching to see them together, it made you laugh in a hushed, fascinated way. That was in August. A week after I left Santa Barbara Tom ran into a wagon on the Ventura road one night and ripped a front wheel off his car. The girl who was with him got into the papers too because her arm was broken, she was one of the chambermaids in the Santa Barbara Hotel" (Fitzgerald, 1925:143).

"Well, she was less than an hour old and Tom was God knows where. I woke up out of the ether with an utterly abandoned feeling and asked the nurse right away if it was a boy or a girl. She told me it was a girl, and so I turned my head away and wept. 'All right,' I said, 'I'm glad it's a girl. And I hope she'll be a fool-that's the best thing a girl can be in this world, a beautiful little fool." "You see I think everything's terrible anyhow," she went on in a convinced way. "Everybody thinks so-the most advanced people. And I know. I've been everywhere and seen everything and done everything." Her eyes flashed around her in a defiant way, rather like Tom's, and she laughed with thrilling scorn. "Sophisticated-God, I'm sophisticated!" "The instant her voice broke off, ceasing to compel my attention, my belief, I felt the basic insincerity of what she had said. It made me uneasy, as though the whole evening had been a trick of some sort to exact a contributory emotion from me. I waited, and sure enough, in a moment she looked at me with an absolute smirk on her lovely face as if she had asserted her membership in a rather distinguished secret society to which she and Tom belonged." (Fitzgerald, 1925:118-120)

In this passage, Daisy pulls Nick aside in Chapter 1 and claims, despite her outward happiness and luxurious lifestyle, she's quite depressed by her situation. "I never loved him," she said, with perceptible reluctance. "Not at Kapiolani?" demanded Tom suddenly. "No."

From the ballroom beneath, muffled and suffocating chords were drifting up on hot waves of air.

"Not that day I carried you down from the Punch Bowl to keep your shoes dry?" There was a husky tenderness in his tone. ". . . Daisy?" (Fitzgerald, 1925:258-62)

Both Tom and Daisy enter or continue affairs, pulling away from each other instead of confronting the problems in their marriage. However, Gatsby forces them to confront their feelings in the Plaza Hotel when he demands Daisy say she never loved Tom. Although she gets the words out, she immediately rescinds them "I did love [Tom] once but I loved you too!" after Tom questions her. Tom breaks down, speaking with "husky tenderness" and recalling some of the few happy moments in his and Daisy's marriage. This is a key moment because it shows despite the disfunction of their marriage, Tom and Daisy seem to both 
seek pleasure in happy early memories. Between those few happy memories and the fact that they both come from the same social class, their marriage ends up weathering multiple affairs.

Daisy and Tom were sitting opposite each other at the kitchen table with a plate of cold fried chicken between them and two bottles of ale. He was talking intently across the table at her and in his earnestness his hand had fallen upon and covered her own. Once in a while she looked up at him and nodded in agreement. They weren't happy, and neither of them had touched the chicken or the ale-and yet they weren't unhappy either. There was an unmistakable air of natural intimacy about the picture and anybody would have said that they were conspiring together. (Fitzgerald, 1925:409-10). They were careless people, Tom and Daisythey smashed up things and creatures and then retreated back into their money or their vast carelessness or whatever it was that kept them together, and let other people clean up the mess they had made. . . . (Fitzgerald, 1925:.146). By the end of the novel, after Daisy's murder of Myrtle as well as Gatsby's death, she and Tom are back together, "conspiring" and "careless" once again, despite the deaths of their lovers. As Nick said, they "weren't happy...and yet they weren't unhappy either." Their marriage is important to both of them, since it calm down their status as old money aristocracy and brings stability to their lives. So the novel ends with them once again described as a unit, a "they," perhaps even more strongly bonded since they've survived not only another round of affairs but murder, as well.

\subsection{Myrtle and George Marriage Descriptions}

In contrast to Tom and Daisy, Myrtle and George were married 12 years before the start of the novel. Maybe people think that since they've been married for four times as long, their marriage is more stable. In fact, in contrast from Tom and Daisy's unified front, Myrtle and George's marriage appears not harmonic from the beginning. Although Myrtle was taken with George at first, she overestimated his money and "breeding" and found herself married to a mechanic and living over a garage in Queens, a situation she's apparently unhappy with (Fitzgerald, 1925:.112). However, divorce was uncommon in the 1920s, and furthermore, the working-class Myrtle doesn't have access to wealthy family members or any other real options, so she stays married, perhaps because George is quite devoted and even in some ways subservient to her. A few months before the beginning of the novel in 1922, she begins an affair with Tom Buchanan, her first affair (Fitzgerald, $1925: 117)$. She sees the affair as a way out of her marriage, but Tom sees her as just another disposable mistress, leaving her desperate and vulnerable once George finds out about the affair. I heard footsteps on a stairs and in a moment the thickish figure of a woman blocked out the light from the office door. She was in the middle thirties, and faintly stout, but she carried her surplus flesh sensuously as some women can. Her face, above a spotted dress of dark blue crepe-de-chine, contained no facet or gleam of beauty but there was an immediately perceptible vitality about her as if the nerves of her body were continually smouldering. She smiled slowly and walking through her husband as if he were a ghost shook hands with 
Tom, looking him flush in the eye. Then she wet her lips and without turning around spoke to her husband in a soft, coarse voice: "Get some chairs, why don't you, so somebody can sit down." "Oh, sure," agreed Wilson hurriedly and went toward the little office, mingling immediately with the cement color of the walls. A white ashen dust veiled his dark suit and his pale hair as it veiled everything in the vicinity-except his wife, who moved close to Tom. (Fitzgerald, 1925:115-17) George is despair and thus seem in the hopelessness and depression of the condition, while Myrtle is alluring and full of vitality. In contrast to Tom and Daisy, who are initially presented as a unit, first introduction to George and Myrtle shows them fractured, with different personalities and motivations. We get the sense right away that their marriage is in trouble, and conflict between the two will behappen

"I married him because I thought he was a gentleman," she said finally. "I thought he knew something about breeding, but he wasn't fit to lick my shoe."

"You were crazy about him for a while," said Catherine. "Crazy about him!" cried Myrtle incredulously. "Who said I was crazy about him? I never was any more crazy about him than I was about that man there." (Fitzgerald, 1925:112-4). Here a story about George and Myrtle's marriage: like Daisy, Myrtle was crazy about her husband at first but the marriage has not harmonic. But while Daisy doesn't have any real desire to leave Tom, here could see Myrtle want to leave, and very dismissive of her husband. Myrtle seems to suggest that even having her husband wait on her is unacceptable, it's clear she thinks she is finally move for bigger and better things. "Beat me!" he heard her cry.
"Throw me down and beat me, you dirty little coward!" A moment later she rushed out into the dusk, waving her hands and shouting; before he could move from his door the business was over. (Fitzgerald, 1925:314-5). We don't know what happened in the fight before this crucial moment, but we do know George locked Myrtle in a room once he figured out she was having an affair. So despite the outward appearance of being ruled by his wife, he does, in fact, have the ability to physically control her. However, he apparently doesn't hit her, the way Tom does, and Myrtle yelled him for it, perhaps insinuating he's less gently than Tom. This outbreak of both physical violence (George locking up Myrtle) and emotional abuse (probably on both sides) fulfills the earlier sense of the marriage being headed for conflict. Still it's disturbing to witness the last few minutes of this fractured, unstable partnership.

\subsection{Daisy and Gatsby Relationship Description}

Jay Gatsby (who learned from Dan Cody how to act like one of the wealthy) was placed in Louisville before going to fight in World War I. In Louisville, he met Daisy Fay, a beautiful young girl (10 years his junior), who took him for someone of her social class. Gatsby maintained the lie, which allowed their relationship to progress. Gatsby fell in love with Daisy and the wealth she represents, but he had to leave for the war and by the time he returned to the US in 1919, Daisy has married Tom Buchanan. Determined to get her back, Gatsby falls in with Meyer Wolfshiem, a gangster, and gets into a criminal company to make enough money to finally be able to provide for her. By the beginning of the novel, he is ready to try and win her back over, ignoring the fact she has been married to Tom for three 
years and has a child. In the first chapter, there are few dialogues about Gatsby, but one of the most interesting is Daisy immediately happy when heard his name.

She obviously still remembers him and perhaps even thinks about him, but her surprise suggests that she thinks he's gone for a long time. "Gatsby bought that house so that Daisy would be just across the bay. "Then it had not been merely the stars to which he had aspired on that June night. He came alive to me, delivered suddenly from the womb of his purposeless splendor. (Fitzgerald, 1925:151-2) In Chapter 4, Daisy and Gatsby's story from Jordan: specifically, how they dated in Louisville but it ended when Gatsby went to the front. She also explains how Daisy threatened to call off her marriage to Tom after receiving a letter from Gatsby, but of course ended up marrying him anyway (Fitzgerald, 1925:.140). Here also know the fact that Gatsby's primary motivation is to get Daisy back, while Daisy is of course in the dark about all of this. This sets the stage for their affair being on unequal footing: while each has love and affection for the other, Gatsby has thought of little else but Daisy for five years while Daisy has created a whole other life for herself. "We haven't met for many years," said Daisy, her voice as matter-of-fact as it could ever be. "Five years next November." (Fitzgerald, 1925:.69-70). Daisy and Gatsby finally reunite in Chapter 5. The entire chapter is important for understanding the Daisy/Gatsby relationship, since we actually see them interact for the first time. But this initial dialogue is fascinating, because we see that Daisy's memories of Gatsby are unclear, while Gatsby has been so obsessed with her. They were sitting at either end of the couch looking at each other as if some question had been asked or was in the air, and every vestige of embarrassment was gone. Daisy's face was smeared with tears and when I came in she jumped up and began wiping at it with her handkerchief before a mirror. But there was a change in Gatsby that was simply confounding. He literally glowed; without a word or a gesture of exultation a new well-being radiated from him and filled the little room. (Fitzgerald, 1925:.87). After awkward reintroduction, Nick leaves Daisy and Gatsby alone and comes back to find them talking freely and emotionally. Gatsby has transformed, he is charming and glowing. "They're such beautiful shirts," she sobbed, her voice muffled in the thick folds. "It makes me sad because I've never seen such-such beautiful shirts before." (Fitzgerald, 1925:118).

Gatsby gets the chance to show off his mansion and enormous wealthy to Daisy, and she breaks down after a very conspicuous display of Gatsby's wealth, through his many color shirts. In Daisy's tears, it might feel a bit of guilt because Gatsby reach so much just for her or perhaps regret, that she might have been able to be with him had she had the strength to walk away from her marriage with Tom. Still, unlike Gatsby, whose motivations are decrease, it's hard to know what Daisy is thinking and how invested she is in their relationship, despite how openly emotional she is during this reunion. Perhaps she's just overcome with emotion due to reliving the emotions of their first meeting. His heart beat faster and faster as Daisy's white face came up to his own. He knew that when he kissed this girl, and forever wed his unutterable visions to her perishable breath, his mind would never romp again like the mind of God. So he waited, listening for a moment longer to the tuning fork that had been struck upon a star. Then he kissed her. At his lips' touch she blossomed for him like a flower 
and the incarnation was complete. (Fitzgerald, 1925:134). In flashback, about Daisy and Gatsby's first kiss, through Gatsby's point of view. It can be seen explicitly in this scene that, for Gatsby, Daisy has come to represent all of his larger hopes and dreams about wealth and a better life, she is literally the realization of his dreams. There is no analogous passage about Daisy, because we actually don't know that much of Daisy's inner life, or certainly not much compared to Gatsby.

The relationship is not balance, Gatsby has literally give his heart and soul into it, while Daisy, though she obviously has love and affection for Gatsby, hasn't have same feelings in the same way. It becomes clear here that Daisy can never live up to Gatsby's huge hoping of her. "Oh, you want too much!" she cried to Gatsby. "I love you now-isn't that enough? I can't help what's past." She began to sob helplessly. "I did love him once-but I loved you too." Gatsby's eyes opened and closed. "You loved me too?" he repeated. (Fitzgerald, 1925:264-66). Here is about Daisy's real feelings. She loved Gatsby, but also Tom, and to her those were equal loves. Gatsby's obsession with her appears shockingly one-sided at this point, and it's clear if she will not leave Tom for him. It also can be seen why this confession is like a punch to Gatsby: he's been dreaming about Daisy for years and sees her as his one true love, while she can't even calculate her love for Gatsby above her love for Tom. Despite Daisy's rejection of Gatsby back at the Plaza Hotel, he refuses to believe that it was real and is sure that he can still get her back. His devotion is so intense he doesn't think twice about covering for her and taking the blame for Myrtle's death. In fact, his obsession is so strong he barely seems to register that there's been a death, or to feel any guilt at all. This moment clearly explain about how much Daisy means to Gatsby, and how comparatively little he means to her.

\subsection{Tom and Myrtle Relationship Description}

Myrtle sees the affair as romantic and out of her marriage, while Tom sees it as just another affair, and Myrtle as one of a string of mistresses. The pair has physical chemistry and attraction to each other.

"I think it's cute," said Mrs. Wilson enthusiastically. "How much is it?" "That dog?" He looked at it admiringly. "That dog will cost you ten dollars." The airedale-undoubtedly there was an airedale concerned in it somewhere though its feet were startlingly whitechanged hands and settled down into Mrs. Wilson's lap, where she fondled the weather-proof coat with rapture.

Is it a boy or a girl?" she asked delicately. "That dog? That dog's a boy." "It's a bitch," said Tom decisively. "Here's your money. Go and buy more dogs with it." (Fitzgerald, 1925:38-43).

This passage is great because it shows Tom and Myrtle's different attitudes toward the affair. Myrtle thinks that he cares about her more than he really does. But to Tom, the money isn't a big deal. He casually throws away the 10 dollars, aware he's being scammed but not caring, since he has so much money at his disposal.

Myrtle pulled her chair close to mine, and suddenly her warm breath poured over me the story of her first meeting with Tom.

"It was on the two little seats facing each other that are always the last ones left on the train. I was going up to New York to see my sister and spend the night. He had on a dress suit and patent leather shoes and I couldn't keep my eyes off him but every time he looked at me I had to pretend to be looking at the 
advertisement over his head. When we came into the station he was next to me and his white shirt-front pressed against my arm-and so I told him I'd have to call a policeman, but he knew I lied. I was so excited that when I got into a taxi with him I didn't hardly know I wasn't getting into a subway train. All I kept thinking about, over and over, was 'You can't live forever, you can't live forever.' " (Fitzgerald, 1925:119-20)

Myrtle, twelve years into a marriage she's unhappy in, sees her affair with Tom as a romantic escape. She tells the story of how she and Tom met like it's the beginning of a love story. In reality, it's pretty creepy. Tom sees a woman he finds attractive on a train and immediately goes and presses up to her like and convinces her to go sleep with him immediately.

Sometime toward midnight Tom Buchanan and Mrs. Wilson stood face to face discussing in impassioned voices whether Mrs. Wilson had any right to mention Daisy's name.

"Daisy! Daisy! Daisy!" shouted Mrs. Wilson. "I'll say it whenever I want to! Daisy! Dai-—"

Making a short deft movement Tom Buchanan broke her nose with his open hand. (Fitzgerald, 1925:124-6)

In case it was still wondering that perhaps Myrtle's take on the relationship had some basis in truth, this is a hard reality. Tom's bad treatment of Myrtle reminds of his brutality and the fact that, to him, Myrtle is just another affair, and he would never leave Daisy for her.

There is no confusion like the confusion of a simple mind, and as we drove away Tom was feeling the hot whips of panic. His wife and his mistress, until an hour ago secure and inviolate, were slipping precipitately from his control. (Fitzgerald, 1925:164)

Chapter 2 gives lots of insight into Myrtle's character and how she sees her affair with Tom. But other than Tom's physical attraction to Myrtle, but it is not clear about a view of his motivations until later on. In Chapter 7, Tom panics once he finds out George knows about his wife's affair. It can conclude that control is incredibly important to Tom include control of his wife, control of his mistress, and control of society more generally.

"And if you think I didn't have my share of suffering-look here, when I went to give up that flat and saw that damn box of dog biscuits sitting there on the sideboard I sat down and cried like a baby. By God it was awful-_" (Fitzgerald, 1925:145)

Despite Tom's behavior throughout the novel, at the very end, Nick leaves with an image of Tom confessing to crying over Myrtle. This complicates the reader's desire to see Tom as a straightforward villain.

\subsection{Nick and Jordan Relationship Description}

Nick and Jordan are the only couple without any prior contact before the novel begins (aside from Nick apparently seeing her photo once in a magazine and hearing about her attempt to cheat). Jordan is a friend of Daisy's who is staying with her, and Nick meets Jordan when he goes to have dinner with the Buchanans. I enjoyed looking at her. She was a slender, smallbreasted girl, with an erect carriage which she accentuated by throwing her body backward at the shoulders like a young cadet. Her grey sun-strained eyes looked back at me with polite reciprocal curiosity out of a wan, charming discontented face. It occurred to me now that I had seen her, or a picture of her, somewhere before. (Fitzgerald, 1925:57)

As Nick eyes Jordan in Chapter 1 , it could see from his immediate physical attraction to her, though it's not as potent as Tom's to Myrtle. And similar to Gatsby's attraction to Daisy being to her money and voice, Nick is pulled in by 
Jordan's posture, her attitude and status are more charming than her looks alone. Nick's attraction to Jordan gives us a bit of insight both in how Tom sees Myrtle and how Gatsby sees Daisy.

"Good night, Mr. Carraway. See you anon."

"Of course you will," confirmed Daisy. "In fact I think I'll arrange a marriage. Come over often, Nick, and I'll sort of-oh-fling you together. You know-lock you up accidentally in linen closets and push you out to sea in a boat, and all that sort of thing--" (Fitzgerald, 1925:131-2)

Throughout the novel, Nick avoiding getting caught up in relationships the woman he mentions back home, the woman he dates briefly in his office, Myrtle's sister though he doesn't protest to being "flung together" with Jordan. Perhaps this is because Jordan would be a step up for Nick in terms of money and class, which speaks to Nick's ambition and class-consciousness, despite the way he paints himself as an everyman. Furthermore, unlike these other women, she lets Nick come to her. Nick sees attracted to how detached and cool she is. "You're a rotten driver," I protested. "Either you ought to be more careful or you oughtn't to drive at all." "I am careful." "No, you're not."

"Well, other people are," she said lightly. "What's that got to do with it?"

"They'll keep out of my way," she insisted. "It takes two to make an accident." "Suppose you met somebody just as careless as yourself."

"I hope I never will," she answered. "I hate careless people. That's why I like you." Her grey, sun-strained eyes stared straight ahead, but she had deliberately shifted our relations, and for a moment I thought I loved her. (Fitzgerald, 1925:162-70) Here, Nick is attracted to Jordan's bored attitude and her confidence that others will avoid her careless behavior, an attitude she can afford because of her money. So just as Gatsby falls in love with Daisy and her wealthy status, Nick also seems attracted to Jordan for similar reasons.

"It was dark now, and as we dipped under a little bridge I put my arm around Jordan's golden shoulder and drew her toward me and asked her to dinner. Suddenly I wasn't thinking of Daisy and Gatsby any more but of this clean, hard, limited person who dealt in universal skepticism and who leaned back jauntily just within the circle of my arm. A phrase began to beat in my ears with a sort of heady excitement: "There are only the pursued, the pursuing, the busy and the tired." (Fitzgerald, 1925:164)

Nick, again with Jordan, seems interested to be with someone who is a step above him in terms of social class, interest to be a "pursuing" person, rather than just busy or tired. And again, we get a sense of what attracts him to Jordan, her clean, hard, limited self, her skepticism, and confidence attitude. It's interesting to see these qualities become cringe to Nick just a few chapters later.

Just before noon the phone woke me and I started up with sweat breaking out on my forehead. It was Jordan Baker; she often called me up at this hour because the uncertainty of her own movements between hotels and clubs and private houses made her hard to find in any other way. Usually her voice came over the wire as something fresh and cool as if a divot from a green golf links had come sailing in at the office window but this morning it seemed harsh and dry.

"I've left Daisy's house," she said. "I'm at Hempstead and I'm going down to Southampton this afternoon."

Probably it had been tactful to leave Daisy's house, but the act annoyed me and her next remark made me rigid.

"You weren't so nice to me last night." 
"How could it have mattered then?" (Fitzgerald, 1925:49-53)

Later in the novel, after Myrtle's tragic death, Jordan's casual, devil-may-care attitude is no longer cute, in fact Nick finds it disgusting. In this phone conversation, we see Nick's infatuation with Jordan ending, replaced with the realization that Jordan's casual attitude is indicative of everything Nick hates about the rich, old money group. Nick's relationship with Jordan represents how his feelings about the wealthy have evolved, at first he was drawn in by their cool, attitudes, but eventually found himself refused by their carelessness and cruelty.

She was dressed to play golf and I remember thinking she looked like a good illustration, her chin raised a little, jauntily, her hair the color of an autumn leaf, her face the same brown tint as the fingerless glove on her knee. When I had finished she told me without comment that she was engaged to another man. I doubted that though there were several she could have married at a nod of her head but I pretended to be surprised. For just a minute I wondered if I wasn't making a mistake, then I thought it all over again quickly and got up to say goodbye.

"Nevertheless you did throw me over," said Jordan suddenly. "You threw me over on the telephone. I don't give a damn about you now but it was a new experience for me and I felt a little dizzy for a while."

We shook hands.

"Oh, and do you remember - " she added, "- - a conversation we had once about driving a car?"

"Why-not exactly."

"You said a bad driver was only safe until she met another bad driver? Well, I met another bad driver, didn't I? I mean it was careless of me to make such a wrong guess. I thought you were rather an honest, straightforward person. I thought it was your secret pride."

"I'm thirty," I said. "I'm five years too old to lie to myself and call it honor." (Fitzgerald, 1925:129-135)

In their official break-up, Jordan calls out Nick for claiming to be honest and straightforward but in facts being prone to lying himself. So even Nick is disappointed in Jordan's behavior, Jordan is disappointed to find another "bad driver" in Nick, and both seem agree that they would never work as a couple. It's interesting to see Nick called out for dishonest behavior for once. For all of his judging of others, he's clearly not a paragon of virtue, and Jordan clearly recognizes that.

This break-up is also interesting because it's the only time we see a relationship end because the two members choose to walk away from each other, all the other failed relationships (Daisy/Gatsby,Tom/Myrtle,Myrtle/

George) ended because one or both died. So perhaps there is a safe way out of a bad relationship in Gatsby - to walk away early, even if it's difficult and you're still "half in love" with the other person (Fitzgerald, 1925:136).

\section{Discussion}

After presenting the characteristics of women in The Great Gatsby by F. Scott Fitzgerald, the researcher intended to discuss the findings and how they answer the research questions based on the first chapter.

The first question focuses on the main character of women in The Great Gatsby by F. Scott Fitzgerald. There were three women characters in the novel, those were: Daisy Buchanan, Jordan Baker and Myrtle Wilson. The researcher limited the women character because there were 
only third of them who have main role and mostly appeared in every chapter of The Great Gatsby by F. Scott Fitzgerald, whereas Nurgiyantoro (1998) named this as major character.

Based on the data above, there were found some characteristics of main women character in The Great Gatsby by F. Scott Fitzgerald. Daisy Buchanan or Daisy Fay Buchanan have two main characteristics which is always appear and become attention in every single chapter, there are: pessimistic and materialistic. Second is Jordan Baker, who is two years younger than Daisy Buchanan also have two main characteristics, there are Masculine and Worried. The last women character is Myrtle Wilson, in this character, the researcher only found one characteristic that always appear from this character, it is materialistic.

From the explanation, it concluded if every main character has characteristics which is almost same because The Great Gatsby have a theme about relationship, love, wealthy and materialism. It also related with the explanation of Kartono (1992) about characteristics of women, he stated if women are more emotional, relate everything to emotional feelings, more passive and the totality of women character not on the objective awareness but on her feeling.

Hence, the novel portrayed the women character in The Great Gatsby by F. Scott Fitzgerald first by money and materialism, it could be seen from the opening pages, Nick establishes himself as someone who has had many advantages in life, a wealthy family and an Ivy League education to name just two. Despite not being as wealthy as Tom and Daisy, his second cousin, they see him as enough of a peer to invite him to their home in Chapter 1. Nick's connection to Daisy in turn makes him attractive to Gatsby. If Nick were just a middle-class everyman, the story could not play out in the same way. Tom and Daisy's movements are also supported by their money. At the beginning of the novel they move to fashionable East Egg, after moving around between "wherever people played polo and were rich together," and are able to very quickly pick up and leave at the end of the book after the murders, thanks to the protection their money provides (Fitzgerald, 1925: 17).

Daisy, for her part, only begins her affair with Gatsby after a very detailed display of his wealth (via the mansion tour). She even breaks down in tears after Gatsby shows off his ridiculously expensive set of colored shirts, crying that she's "never seen such beautiful shirts" before (Fitzgerald, 1925: 118). Gatsby's notoriety comes from, first and foremost, his enormous wealth, wealth he has gathered to win over Daisy. Gatsby was born to poor farmer parents in North Dakota, but at 17, determined to become rich, struck out with the wealthy Dan Cody and never looked back (Fitzgerald, 1925: 5-15). Even though he wasn't able to inherit any part of Cody's fortune, he used what he learned of wealthy society to first charm Daisy before shipping out to World War I. Then, after returning home and realizing Daisy was married and gone, he set out to earn enough money to win Daisy over, turning to crime via a partnership with Meyer Wolfshiem to quickly amass wealth (Fitzgerald, 1925: 83-87).

Meanwhile, Tom's mistress Myrtle, a car mechanic's wife, puts on airs and tries to pass as rich through her affair with Tom, but her involvement with the Buchanans gets her killed. George Wilson, in contrast, is constrained by his lack of wealth. He tells Tom Buchanan after finding out about Myrtle's affair that he plans to move her West, but he "[needs] money pretty bad" in order to make the 
move (Fitzgerald, 1925: 146). Tragically, Myrtle is hit and killed that evening by Daisy.

If George Wilson had had the means, he likely would have already left New York with Myrtle in tow, saving both of their lives. Hardly anyone shows up to Gatsby's funeral since they were only attracted by his wealth and the parties, not the man himself. This is encapsulated in a phone call Nick describes, to a man who used to come to Gatsby's parties: "one gentleman to whom I telephoned implied that he had got what he deserved. However, that was my fault, for he was one of those who used to sneer most bitterly at Gatsby on the courage of Gatsby's liquor and I should have known better than to call him" (Fitzgerald, 1925: 69).

The next portrayal is about love and relationship. That are became a major motivator for nearly every character in The Great Gatsby. However, none of Gatsby's five major relationships is depicted as healthy or stable. Gatsby's portrayal of love and desire is complex. The relationship consists of five major relationships: Daisy/Tom, George/Myrtle, Gatsby/Daisy, Tom/Myrtle, and Jordan/Nick.

Materialism and relationship have a strong connection with 1920s era, because the author made a story in relation to how people viewed women in the 1920. The 1920 also known as the Roaring Twenties, was a big era as more women becoming a symbol of change. Within the next few years, women would be known for marital status, fashion and work opportunities. women would be guaranteed more freedom and equality. These would be critical points to show how people's view on women have changed throughout society.

The last is how American and Indonesian women portrayed. From
American women in the novel there are 4 characteristics that mostly occur in each of them, first Daisy is Pessimistic and it could be seen from the Chapter 1 in the novel, Daisy also sad about her role in the world. Second is materialistic, it informs from Daisy and Gatsby reunion, she is delighted by Gatsby's mansion but falls to pieces after Gatsby shows off his collection of shirt and also from Myrtle Wilson who isn't happy with her marriage with George Wilson because he doesn't have a wealthy. Third there is Jordan Baker's characteristic; masculine because she is an athlete and have hobbies like men (golf and car).

The last also came from Jordan Baker, she has worried personality because in the novel she described as someone who carefully calculate risks, include in driving and relationship. Different with American, Indonesian women also have their own character. First start from optimistic, loyal and optimism and it have an educational value based on Raden Ajeng Kartini's movements.

\section{CONCLUSION}

The researcher concludes that there are several characteristics found in major women character in The Great Gatsby. First start from Daisy Buchanan, there are two characteristics of this character: She is pessimistic and also materialistic. Second is Jordan Baker, she is look different with another character because she looks more masculine and optimistic, but she has a trauma in her past relationship so she is little bit worried. The last is Myrtle Wilson, from the first story, she depressed because of her marriage. She is highly materialistic so that's why she has an affair with Tom Buchanan.

The researcher also explains how does the portrayal of women in The Great Gatsby. Because this novel is come from 
1920s as a Roaring Twenties, so the novel took a theme about money, materialism, love and relationship. It's become a general theme of the novel because the author related with the era.

The last is how is the portrayal of women in this novel and women in Indonesia, first from the novel there are 3 characteristics that occur in the character: Pessimistic, materialistic, and masculine. From Indonesian women on the education, there 3 that mostly appear: feminism, optimistic, loyal

\section{SUGGESTIONS}

Based on the results and discussion of this research, there were some suggestions that the researcher intended to convey:

First, for students whose major is English Department, studying English not only about four basic skills, but they must study other aspect of English, include literature. Moreover, we have to know about other aspect such as history, culture, and other. One of them throughout the novel. As we know, novel is one of media to learn in order to know the history, the culture, the country and also to teach students to have critical thinking, because from the novel, they can maximize the analogical thinking. Second for the academic fields, especially for lecturers and teachers who read the finding of this study, the writer wishes that they will be mentors/tutors for other researchers in analyzing novel. The writer also hopes that the lecturer may give more understanding about novel, especially dealing with analyzing characteristics and also relate it to the history of the country in order to help students to get more understanding about the analyzing of novel and the function of novel as a media for learning English.

Third, the writer also hopes that the further research can give a great contribution to make an analyzing of characteristics of character in novel and relate to another history or culture of a country and they will find better ideas to improve more better findings in order to make a novel as a good media for students learning process and also to English language teaching.

The last for the reader, the writer fully realizes that this paper is still far from being perfect, therefore any constructive criticisms will be highly appreciated.

\section{REFERENCES}

Arikunto, S. (1998). Prosedur Penelitian Suatu Pendekatan Praktek. Jakarta : PT. Rineka Cipta. Jakarta.

Allport, G. W. (1937). Personality: A Psychological Interpretation. New York: Holt.

Burhan, Nurgiyantoro. 1998. Teori Pengkajian Sastra. Bulaksumur. Yogyakarta: Gadjah Mada University Press.

Candra, Septiana. 2001. An Analysis of Women Characters in Novel "Emma" by Jane Austen. Bengkulu: Bengkulu University Press.

Collins, Gail. 2007. America's Women: 400 Years of Dolls, Drudges, Helpmates, and Heroines (P.S.) America. Harper Perennial Press.

Damayanti, Indah. 2013. Feminine Identities in John Steinbeck's Short Stories. Bengkulu: Bengkulu University Press.

Dumovska, Daniela. 2010. The Women in Charles Dickens's Novel Oliver Twist. Sweden: Halmstad University Press.

Jabrohim. 2003. Metodologi Penelitian Sastra. Yogyakarta: Hanindita Graha Widya.

Johan, Theodorus. 2008. The Images of Wife and Mother in Kate Chopin's Narratives: A Feminist Reading. 
Bandung: Maranatha Christian

University Press.

Kartono, Kartini. 1992. Psikologi Wanita, Mengenal Gadis Remaja dan Wanita Dewasa. Bandung: Mandar Maju.

Klarer, Mario. 2004. An Introduction to Literary Studies Second Edition. New York: Roudledge.

Korhonen, Jani. 2006. The Portrayal of Women in the Novels of Charles Bukowski. Sweden. Lulea University of Technology Press.

Nyoman, Kutha Ratna. 2005. Sastra dan Cultural Studies: Representasi Fiksi dan Fakta. Yogyakarta: Pustaka Pelajar

Pritchett, V. S (1964) "The Young Gorky", in his The Living Novel, New York: Random House, revised edition, 1964 (original edition, 1946).

Reeve, Clara. 1785. The Progress of Romance. New York: Facsimile Text Society.

Tarigan, Henry Guntur. (1985). Pengajaran Gaya Bahasa. Bandung: Angkasa.

Watson, Adam (1992). The Evolution of InternationalSociety: A Comparative Historical Analysis. Routledge: Great Britain.

Wellek, Rene dan Austin Warren. 1995. Teori Kesusastraan. Jakarta: PT. Gramedia. 